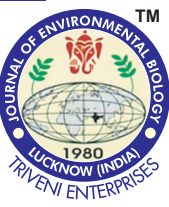

\title{
Reproductive and breeding biology of Schizothorax labiatus, a snow trout found in River Jhelum, Kashmir
}

\begin{tabular}{l}
\hline Paper received: 18.01 .2018 \\
\hline \\
Authors Info \\
I. Farooq ${ }^{1,2}$ F.A. Bhat ${ }^{2 *}$, \\
M.H. Balkhi', T.H. Shah', \\
B.A. Bhat ${ }^{2}$, S. Qadri' ${ }^{2}$ S. Talia ${ }^{5}$, \\
S. Aalia ${ }^{3}$ and P.A. Ganie ${ }^{6}$ \\
${ }^{1}$ Krishi Vigyan Kendra Budgam, \\
Sher-e-Kashmir University of \\
Agricultural Sciences \& Technology \\
of Kashmir, Kashmir-191 111, India \\
${ }^{2}$ Division of Fisheries Resource \\
Management, \\
${ }^{3}$ Division of Aquatic Env. Management, \\
${ }^{4}$ Division of Fishery Extension, \\
Faculty of Fisheries, \\
SKUAST, Kashmir-190 006, India \\
${ }^{5}$ National Fish Seed Farm, \\
Manasbal Kashmir, Department of \\
Fisheries, Kashmir-190 001, India \\
${ }^{6}$ ICAR-Directorate of Coldwater \\
Fisheries Research, \\
Bhimtal- 263 136, India \\
\hline
\end{tabular}

*Corresponding Author Email : fabhat_fb@yahoo.com

\section{Edited by \\ Dr. Munil kumar Sukham}

\section{Reviewed by \\ Dr. Usha Moza \\ Dr. R.B. Raizada}

\section{Abstract}

Aim : Schizothorax labiatus is one of the economically valuable food fish among indigenous schizothoracids (snow trouts), inhabiting the Jhelum River system in Kashmir along with other snow trouts of family Cyprinidae. The present study was conducted to understand and bring forward various reproductive traits of $S$. labiatus inhabiting River Jhelum.

Methodology : The investigation was carried on 310 samples (221 males and 89 females) with total length and total weight ranging between 143 to $350 \mathrm{~mm}$ and 62 to $449 \mathrm{~g}$, respectively, for a period twelve months.

Results : Gonadosomatic index (GSI) was recorded maximum during April for both males (6.19) and females (11.12), indicating that the fish fully matures during this month and spawns during coming months i.e., May when the GSI values start decreasing abruptly. The average values of absolute and relative fecundity in the fish were recorded per gm body weight as 10323 and 42, respectively. Sex ratio was found in 1:0.41 ratio, indicating a significant dominance of males over opposite sex and $L_{m}$, i.e., length at first maturity was estimated to be $196 \mathrm{~mm}$ and the corresponding age at this length was $2+$ years.

Interpretation: The fish breeds once in a year in natural/wild habitat. These findings on reproductive biology of the endemic snow trout, and the influence of environmental conditions on breeding biology will serve as a baseline data towards planning seed production and conservation strategies.

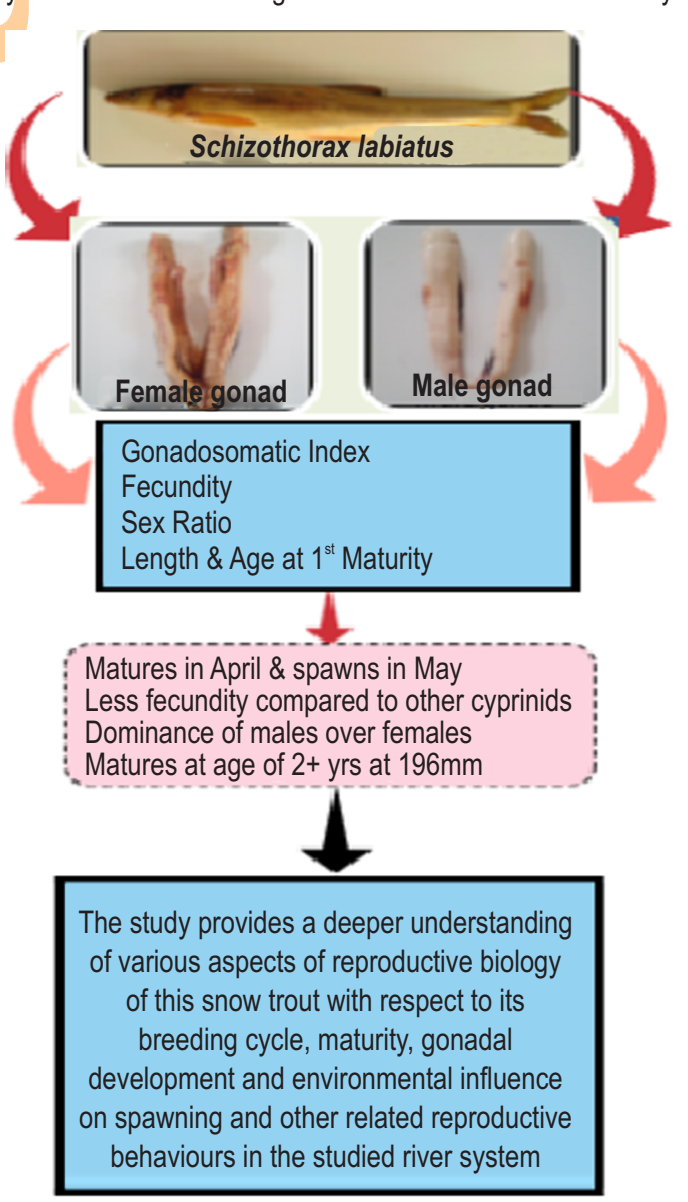

Key words: Breeding biology, Fecundity, Gonadal cycle, Schizothorax labiatus

How to cite : Farooq, I., F.A. Bhat, M.H. Balkhi, T.H. Shah, B.A. Bhat, S. Qadri, S. Talia, S. Aalia and P.A. Ganie: Reproductive and breeding biology of Schizothorax labiatus a snow trout found in River Jhelum, Kashmir . J. Environ. Biol., 40, 291-294 (2019). 


\section{Introduction}

The high altitude waters of Kashmir valley viz. lakes, rivers and springs support chiefly the indigenous fishes and few exotic species. Aquatic systems of valley are dominated by fish species belonging to family Cyprinidae and some from Cobitidae, Siluridae, Salmonidae and Poecilidae. Mostly the fish species inhabiting the Himalayan region are small in size and their size, growth and distribution depends on environmental conditions such as water temperature, velocity of water current, nature of substratum, availability of food and their feeding habits (Yousuf et al., 2003; Bhat et al., 2010). Schizothoracids are the dominant and indigenous cyprinids well adapted to the aquatic habitats of Kashmir.

Encouraging conditions of environment stimulate normal gonad development on which success of reproduction is reliant upon. Almost in all seasonally breeding teleosts, including cyprinids, important controlling factors for reproduction are photoperiod and temperature (Lam, 1983; Shankar et al., 2007; Hontela and Stacey, 1990). Studies related to reproduction of many species indicates that the reproductive cycle of fishes is closely associated to the environmental changes, particularly temperature, day length and food supply influencing gonadal development initiation and fecundity. Determination of the reproductive pattern is an essential component in managing and improving fishery biology of any species (Ragheb, 2016). Comprehensive knowledge and understanding aspects of reproductive biology such as gonadal maturation, size at first maturity, fecundity etc., are essential components in management of fisheries resources (de Carvalho et al., 2009; Fontoura et al., 2009). The process of sexual maturation includes seasonal cycle of gonads, spawning, sex ratio and fecundity (most common measure of assessing reproductive potential in fishes).

In order to plan successful breeding programs and necessary conservation measures, the knowledge of gonadal cycle and their functional mechanism is of prime importance. Being a good indicator of reproductive activity of fish, gonadosomatic index helps in giving details about stages of gonadal maturation (Hojo et al., 2004); and the mean length at which fish gonads ripe for the first time in a given population is length at first maturity $\left(L_{m}\right.$ or $\left.L_{50}\right)$ (Froese and Pauly, 2009). Studies on the reproductive biology of $S$. labiatus in coldwaters, is meagre, therefore the present investigation was carried out to study the reproductive biology of fish by obtaining data on GSI, sex ratio, fecundity, length at first maturity .

\section{Materials and Methods}

The investigation was carried on 310 samples of Schizothorax labiatus collected by random sampling from River Jhelum over a period of 12 months and categorized into different size groups at Fishery Biology Laboratory Faculty of Fisheries. The fish specimens were dissected open and sex was determined. The sex ratio was determined by proportion of relative sexes and any significant divergence from expected 1:1 ratio was tested by Chi-square test (goodness of fit test) as given by Snedecor and Cochran (1967), Zar (1999) and Arshad et al. (2016). The gonads collected were weighed to nearest gram and gonadosomatic index (GSI) was calculated for both the sexes using the gonad weight: body weight ratio given by Qasim (1957 $a, b)$. In order to determine length at first maturity $\left(L_{50}\right)$, histological observation of ovaries was done and proportion of fish with ovaries at stage IV and above maturation was determined in each length group.

Cumulative frequency percentage of mature females during the period was plotted against the length groups of $10 \mathrm{~mm}$ class interval for maturity curve and the length at which $50 \%$ of fishes during the study were mature was taken as $L_{m}$ or $L_{50}$. Fecundity was calculated following gravimetric method (Polder and Zijlstra (1959) by preserving ovaries in Bouins fluid (Bagenal, 1978; Kwei, 1978). Anterior, middle and posterior region of ovary were used to obtain the subsamples (James et al., 1978). The mature ova were counted by evenly spreading out the subsamples on a counting slide with few drops of water. Fecundity or Absolute fecundity was computed by the formula given below:

Fecundity $=\frac{\text { No. of ova in the subsample } x \text { Total ovary weight }}{\text { Weight of subsample }}$

Ratio of fecundity: The ratio of fecundity and weight of fish was used to determine relative fecundity, i.e., number of ova per gm of body weight (Bagenal, 1978). Hard part, i.e., operculum of fish was used for determining age. The opercula were obtained by removing them from the fishes by a scapel and washed in hot water in order to clean it from all extraneous tissue. The bone was then treated with $50 \% \mathrm{H}_{2} \mathrm{O}_{2}$ for about 15 min and washed with water and dried in sun for 2-3 days. Annual rings of growth were seen on these operculum rings. Reading of growth rings for age determination was done following the procedure of Qasim (1973 b).

\section{Results and Discussion}

The present study on S. labiatus is based on collection of fish samples by random sampling from river Jehlum over a period of 12 months. The recorded size of the specimens ranged between $142 \mathrm{~mm}$ and $350 \mathrm{~mm}$ and total weight between $62 \mathrm{~g}$ and $449 \mathrm{~g}$ respectively. Sex ratio indicates the male and female proportion of the population and was expected to be 1:1, deviation from this is often observed in fish indicating segregation or aggregation of sexes according to feeding, breeding, environmental conditions, fishing etc. The monthly data on sex ratio during the present study ranged between minimum 1:0.18 (May) and maximum 1:0.59 (July and November) and was tested against 1:1 using Chi square test which was found significant almost throughout the year at 0.05 level of significance. The average male female ratio was found to be 1:0.41 with clear 
indication of male dominance over females in respect of $S$. labiatus. Similar observations were reported by Shafi (2012) about sex ratio of Carrasius carrasius showing preponderance of males over females (1:0.79). The male dominance over females in $S$. labiatus can be due to several reasons like fishing where females being gravid (i.e., having more girth than males) are caught easily by fishers. Further, the environment factors such as pollution of water bodies and availability of nutritious food seem to be other factors responsible for the dominance of males over females, as males have been reported to require low energy investment in their body development as compared to females (Buxton, 1990).

The mean monthly GSI fluctuated between $1.38 \pm 0.11$ (August) and 6.19 \pm 0.84 (April) in males whereas in females the values fluctuated between $1.80 \pm 0.35$ (August) and $11.12 \pm 2.09$ (April), thus mean GSI values were recorded higher in females compared to that of males. Similar observations were reported by Shafi (2012) in C. carassius. Among reproductive traits, GSI is used widely by biologists in order to indicate the maturity and periodicity of spawning, predicting the breeding season (Joshi et al., 2018). Gonadal development and maturity in fish is indicated by gonadosomatic index (Rheman et al., 2002), besides being useful for determination of fish reproductive period. In the study period between September to April, the mean GSI values showed an increasing trend reaching peak in April then decreasing gradually during the following months and reaching a minimum value in August. The fish spawned during the short period of time and spawns once a year. Similar results were reported in Schizothorax plagiostomus by Jan et al. (2014) from the river Jhelum, Kashmir.

By plotting percentage occurrence of mature females against respective length groups, length at first maturity $L_{m}$ or $L_{50}$ was estimated as length at which $50 \%$ females were mature, as in case of $S$. labiatus $L_{50}$ was recorded as $196 \mathrm{~mm}$. The age as confirmed by the hard part of the fish (operculum) for this $L_{m}$ (196 $\mathrm{mm}$ ) was recorded as $2+$ years. Fecundity was studied by examining 29 preserved mature ovary specimens of the fish collected during the period revealing that total number of mature eggs in the ovary (absolute fecundity) varied between 3857 and 16472 in individuals having ovary weight between $7 \mathrm{~g}$ and $31.2 \mathrm{~g}$ and mature eggs $\mathrm{g}^{-1}$ body weight (relative fecundity) varied between 27 and 74 in individuals having ovary weight between $7 \mathrm{~g}$ and 31.2 g. The recorded value for average absolute fecundity was 10323 and average relative fecundity (per gram body weight) recorded was 42, much lower in $S$. labiatus when compared with other cyprinids and carps at lower elevations of Kashmir Himalaya.

As in the case of $\mathrm{S}$. niger where mean relative fecundity was 48.90 as reported by Hussain et al. (2018). Mekkawy and Hassan (2011) associated changes in fecundity with age, sex, size weight, gonad weight and locality. Fecundity has importance in population assessment, recruitment success and hatchery production of any specie (Mayank et al., 2016). Temperature and other stresses like pollution seem major factors responsible for low fecundity of Schizothoracids as the region falls under temperate type of climate. The present study also revealed that $S$. labiatus McClelland is annual spawner with low fecundity when compared with major carps, releasing eggs over a short period of time, which extends from May to June. Based on the results obtained during the present study, the sex ratio of $S$. labaitus was significantly in favour of males and fish was seen to breed once a year for short period of time in wild/natural habitat after attaining sexual maturity. This study will generate a base line information towards proper management and conservation aspects.

\section{Acknowledgments}

The authors acknowledge timely support and guidance rendered by the Dean, Faculty of Fisheries, scientists and fellow scholars of Faculty of Fisheries, SKUAST-K.

\section{References}

Arshad, A., A.A. Amani, S.M. Nurulamin and F.M. Yusoff: Sex ratio spawning season and the size at maturity of Parapenaeopsis sculptilis (Heller 1862) in the coastal waters of Perak, Peninsular Malaysia. J. Environ. Biol., 37, 709-713 (2016).

Bagenal, T.B.: Aspects of fish fecundity. In: Ecology of Freshwater Fish Production (Ed.:S.D. Gerking). Blackwell Scientific Publications. Oxford. U.K., pp. 75-101 (1978).

Bal, D. V. and K. V. Rao : Oil sardine. In: Marine Fisheries of India. Tata McGraw-Hill Publishing Company Limited, New Delhi, p. 470 (1984).

Bhat, F. A., M.H. Balkhi and A.R. Yousuf: Fish biodiversity in Kashmir Himalayas. In: Biodiversity, Development and Poverty Allevation. Department of Botany, University of Kashmir, pp. $24-27$ (2010).

Biswas, S.P.: Manual of Method in Fish Biology. South Asian Publisher Pvt. Ltd., New Delhi, p. 145 (1993).

Buxton, C.D.:The reproductive biology of Chrysoblephus laticeps and C cristiceps (Teleostei: Sparidae). J. Zoology, 220, 497-511(1990).

De Carvalho, P. A., A. L. Paschoalini, G. B. Santos, E. Rizzo and N. Bazzoli: Reproductive biology of Astyanax fasciatus (Pisces: Characiformes) in a reservoir in Southeastern Brazil. J. Appl. Ichthyol., 25, 306-313 (2009)

Evelyn, R.: Reproductive biology of catfish Chrysichthys auratus, Geoffroy Saint-Hilaire, 1809, (Family: Bagridae) from Damietta branch of the River Nile, Egypt. Egyptian J. Aqu. Res., 42, 349-356 (2016).

Froese, R. and D. Pauly : Fish Base Version (10/2009). World Wide Web Electronic Publication. http://www.fishbase.org (2009).

Hojo, R.E.S., G.B Santos and N. Bazzoli: Reproductive biology of Moenkhausia intermeida (Eigenmann) (Pisces, Characiformes) in Itumbiara Reservoir, Goias. Brazil. Revista Brasileira de Zoologia, 21,519-524 (2004).

Hontela, A. and N.E. Stacey: Cyprinidae: In: Reproductive Seasonality in Teleosts. Environmental Influences (Eds.: A.D. Munro, A.P. Scott and T.J. Lam). CRC Press, Boca Raton, pp. 53-77 (1990).

Hussain, S., F. A. Bhat, H.M. Maqsood, M. H. Balkhi, I. Majid and A. M. Najar: Present status of breeding biology of Schizothorax niger in Dal Lake Kashmir. J. Ento. Zool. Stud., 6, 930-935 (2018).

James, P.S.B.R., T.R. Chendrasekhar Gupta and S.L. Shanbhogue : Some aspects of the biology of ribbon fish, Trichiurus lepturus (Linnaeus). J. Marine Biol.Assam Associ. India, 290, 120-137 (1978).

Jan, M., U. Jan and G.M.Shah : Studies on fecundity and gonadosomatic 
index of Schizothorax plagiostomus (Cypriniformes: Cyprinidae). J. Threat. Taxa., 6, 5375-5379 (2014).

John Fontoura, N.F., A.S. Braun and P.C.C. Milani: Estimating size at first maturity (L) from gonadosomatic index (GSI) data. Neotropical Ichthyology, 7, 217-222 (2009).

Joshi, K. D., S. C. S. Das, R. K. Pathak, A. Khan, U. K. Sarkar and K. Roy: Pattern of reproductive biology of the endangered golden mahseer Tor putitora (Hamilton 1822) with special reference to regional climate change implications on breeding phenology from lesser Himalayan region, India. J. Appli. Animal Res., 46, 1289-1295 (2018).

Khallaf, E.A. and M. Authman: Growth and mortality of Bagrus bayad (Forskal) in Bahr Shebeen Canal. J. Egyptian-German Society of Zool., 4, 87-109 (1991).

Kwei, E.A. : Size composition, growth and sexual maturity of Callinectes latimanus (Rath) in two Ghanaian lagoons. Zool. J. Linnaean Society, 64, 151-175(1978).

Lam, T.J.: Environmental influences on gonadal activity in fishes. In: Fish Physiology (Eds.: W.S. Hoar, D.J. Randall and E.M. Donaldson). Academic Press, New York, USA, IXB. pp. 65-116 (1983).

Mayank, P., A.C. Dwivedi, A. Tiwari: Reproductive profile of Cirrhinus mrigala and suggestion for restoration (Hamilton, 1822) from the Yamuna river, India. Bioved., 27,115-120 (2016).

Mekkawy, I.A.A. and A.A. Hassan: Some reproductive parameters of Synodontis Schall (Bloch and Schneider, 1801) from the River Nile, Egypt. J. Fish. Aquat. Sci., 6, 456-471 (2011).

Moyle, P.B. and J.J. Czech: Fishes: An Introduction to Ichthyology. Prentice-Hall, Inc. Englewood Cliffs, New Jersey (2000).

Polder, J.J.W. and J.J. Zijlstra: Fecundity in the north sea herring International Council for the Exploration of the Sea Conference \& Meeting, Herring Committee, 84 (1959).

Qasim, S Z.: An appraisal of the studies on maturation and spawning In marine teleosts from the Indian waters. Indian Journal of Fisheries, 20, 166-181 (1973a).
Qasim, S. Z.: Some implications of the problems of age and growth in marine fishes from the Indian waters. Indian J. Fisher., 20, 351-371 (1973 b)

Qasim, S.Z.: The biology of Centronotus gunnellus (L.) (Teleostei). J. Animal Ecolo., 26, 389-401 (1957 b).

Qasim,S.Z.: The biology of Blennius pholis L. (Teleostei). Proceedings of Zoological Society London, 128,161-208 (1957 a).

Rheman, S., M.L. Islam, M.M.R. Shah, S. Mondal and M.J. Alam: Observation on the fecundity and gonadosomatic index (GSI) of gray mullet Liza parisa (Ham.). J. Biol. Sci., 2, 690-693 (2002).

Shafi, S.: Study on fecundity and GSI of Carassius carassius (Linneaus, 1758-introduced) from Dal Lake Kashmir. Biol. Agricul. Hlthcare., 2, 68-75(2012).

Shankar, D.S. and R.S. Kulkarni: Tissue cholesterol and serum cortisol level during different reproductive phases of female freshwater fish, Notopterus notopterus (Pallas). J. Environ. Biol., 28, 275-278. (2007).

Snedecor, G.W. and W.G. Cochran: Statistical Methods. $6^{\text {th }}$ Edn. Oxford and IBH Publishing Co., New Delhi, p. 593 (1967).

Snyder, D.E.: Fish eggs and larvae. In: Fisheries Techniques (Eds.: L.A. Nielsen and D.L. Johnson). American Fisheries Society, Bethesda, Maryland, pp.165-197(1983).

Yousuf, A.R., F.A. Bhat, D. Mehdi, S. Ali and M.A. Ahangar: Food and feeding habits of Ghyptosternon reticulatum (McClleland and Griffth) in torrential streams of Kashmir Himalayas. J. Res. Develop., 3, 123-133(2003).

Yousuf, A.R., G. Firdus, M.H. Balkhi and A.K. Pandit: Studies on the length-weight relationship in some cyprinid fish in Manasbal Lake, Kashmir. In : Current Trends in Fish and Fishery Biology and Aquatic Ecology (Eds.: A.R. Yousuf, M.K. Raina and M.Y. Qadri). Department of Zoology, the University of Kashmir, Srinagar, pp. 185-189 (1992).

Zar, J.H.: Biostatistical analysis. $4^{\text {th }}$ Edn., New Jersey: Prentice Hall, 829 (1999). 